\title{
The Continental Shelf Project of the Kingdom of Denmark - status at the beginning of 2010
}

\author{
Christian Marcussen and Martin V. Heinesen
}

The Kingdom of Denmark (Denmark, Faroe Islands and Greenland) ratified the United Nations Convention on the Law of the Sea (UNCLOS) on 16 November, 2004 and this allows for a period of ten years to submit extended continental shelf claims beyond 200 nautical miles (NM) to the Commission on the Limits of the Continental Shelf. To acquire the necessary data for delineating the extended continental shelf, the Continental Shelf Project of the Kingdom of Denmark was launched by the Ministry of Science, Technology and Innovation in cooperation with the Faroese and Greenland governments. Several institutions participate in the project. The technical work for the Greenland part is coordinated by the Geological Survey of Denmark and Greenland (GEUS) and the coordination of the Faroese part is shared between the Faroese Earth and Energy Directorate (Jarðfeingi) and GEUS. Further information can be found on the project website www.a76.dk.

\section{Background}

Article 76 of UNCLOS is the key to future jurisdiction over resources on and below the seabed beyond the $200 \mathrm{NM}$ limit. The right to explore and exploit these resources, which include both non-living resources (hydrocarbons and minerals) and bottom-dwelling living resources, may have significant economic implications. According to Article 76, a variety of scientific and technical data are required to be submitted to the Commission on the Limits of the Continental Shelf. These include geodetic, bathymetric, geophysical and geological data regarding e.g. the $200 \mathrm{NM}$ and $350 \mathrm{NM}$ limits from the territorial baselines, the location of the foot of the continental slope, the $2500 \mathrm{~m}$ isobath and the sediment thickness beyond the foot of the slope. The latter is defined as the point of maximum change in the gradient at the base of the continental slope.

\section{Areas of interest - the Faroe Islands}

The continental shelf of the Faroe Islands extends beyond $200 \mathrm{NM}$ in two geographical regions, here referred to as the Northern and the Southern Area (Figs 1, 2). The geomorphological and geological settings are fundamentally differ- ent in the two areas. Already in the early phase of the project, informal arrangements were made with the neighbouring states for exchange of data, and these data form a significant part of the overall data base in both areas.

Field work has been carried out in 2003, 2004, 2005, 2007 and 2008. A wide range of data and samples has been collected including seismic reflection and refraction data, single- and multibeam echo sounder bathymetric data, sediment cores, marine gravity data and airborne magnetic data.

Northern Area. North of the Faroe Islands (Fig. 1), the continental margin is characterised by a number of ridges and elevated sea-floor highs that extend from the shelf and slope region into the Northern Deep. The most pronounced of these sea-floor highs is the Ægir Ridge, which is an extinct part of the spreading system that created the oceanic sea floor of the Northern Deep. The Northern Deep is a large sedimentary

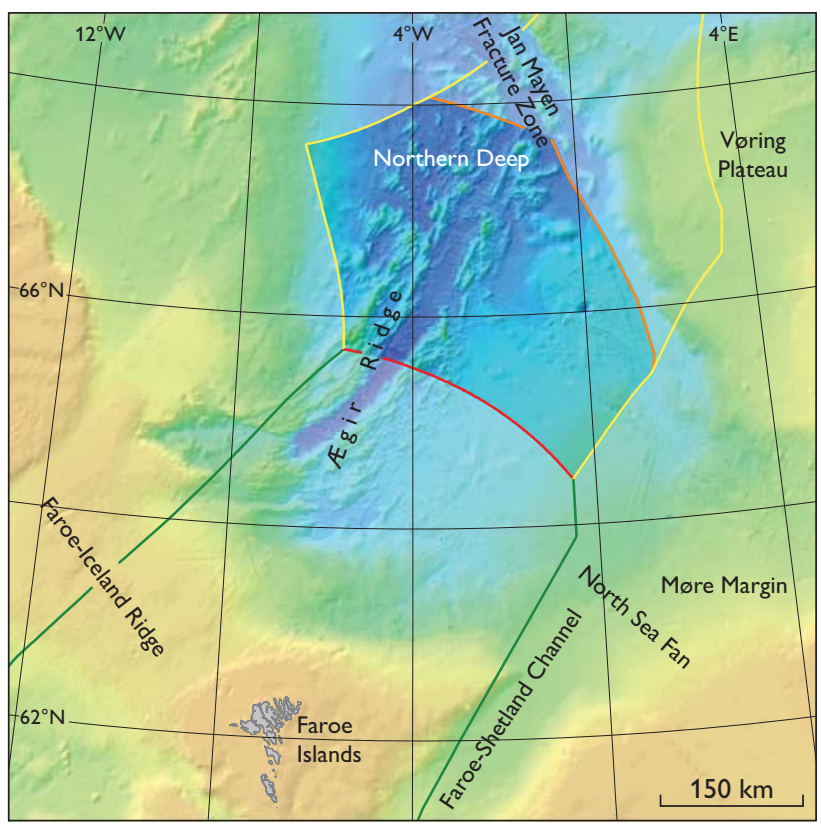

Fig. 1. The Northern Continental Shelf of the Faroe Islands. The continental shelf beyond $200 \mathrm{NM}$ in the area north of the Faroe Islands, as delineated in the submission, amounts to $87792 \mathrm{~km}^{2}$ and is highlighted. Green: agreed borders within 200 NM. Red: Faroese 200 NM limit. Yellow: Iceland's and Norway's EEZ (exclusive economic zone; $200 \mathrm{NM}$ ). Orange: outer limit of the continental shelf. 


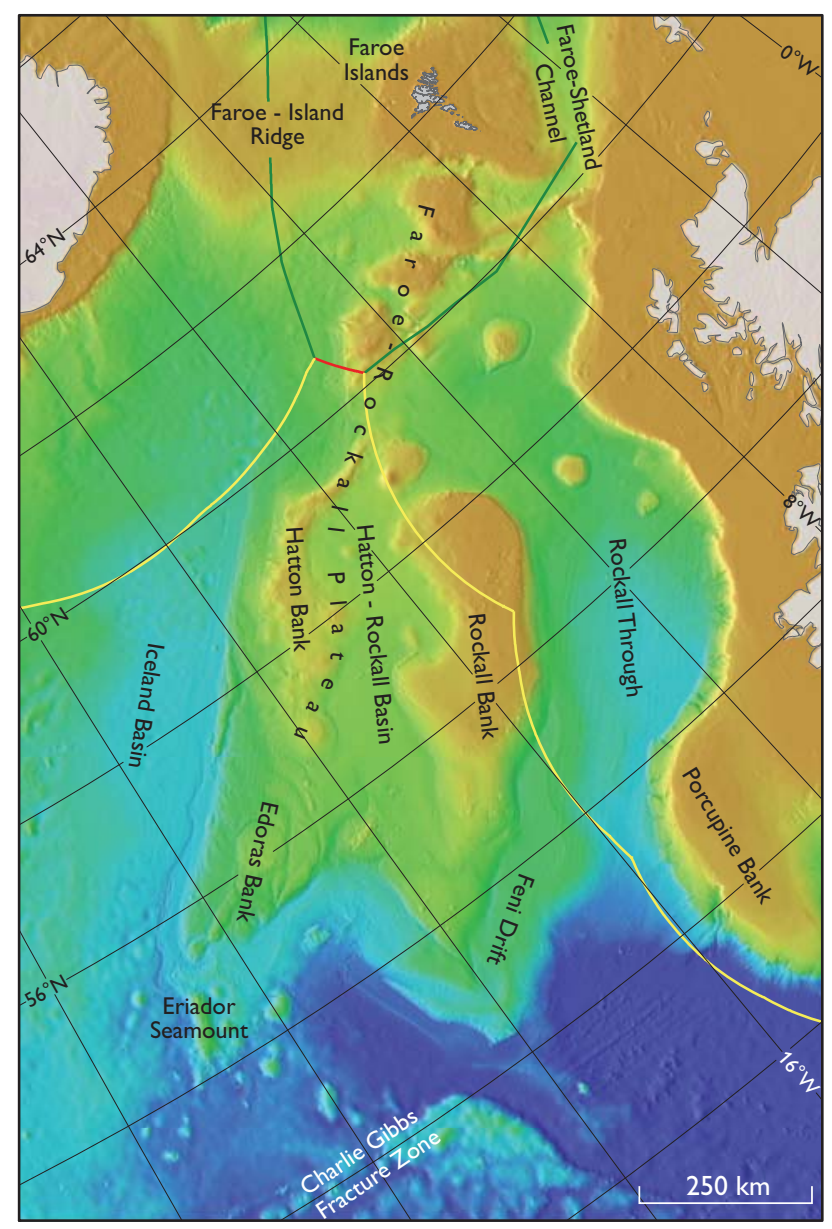

Fig. 2. The Southern Continental Shelf of the Faroe Islands. Green: agreed borders within 200 NM. Red: Faroese 200 NM limit. Yellow: Iceland's, Ireland's and UK's EEZ (200 NM). The outer continental shelf in this area amounts to $c .500000 \mathrm{~km}^{2}$.

basin with sediment thicknesses locally reaching $3 \mathrm{~km}$. The continental margin is strongly affected by slope-related processes (mass wasting, turbidity currents, etc.) and complex erosional and depositional actions of strong ocean currents.

After a period of processing, interpreting and analysing the data in accordance with Article 76 of UNCLOS and the Technical and Scientific Guidelines of the Commission on the Limits of the Continental Shelf (1999), a special task force was established with the responsibility of producing the formal documentation for the Northern Area to be submitted to the Commission. Nine task force members were selected for their expertise in a wide range of geoscientific and legal disciplines and they represent a number of governmental institutions and ministries in Denmark and the Faroe Islands.

The task force initiated its preparation of the submission in April 2008, and by April 2009 the documentation was delivered to the Danish Ministry of Foreign Affairs who for- mally submitted it to the Commission on the Limits of the Continental Shelf on 29 April, 2009 on behalf of the Kingdom of Denmark. On 27 August, 2009 the submission was presented to the Commission by a Danish-Faroese delegation during its 24th formal session.

The continental shelf beyond $200 \mathrm{NM}$ in the area north of the Faroe Islands, as delineated in the submission, amounts to $87792 \mathrm{~km}^{2}$ (Fig. 1). The area overlaps with regions that are also covered by submissions of the two neighbouring states, Norway and Iceland. The three nations have made a mutual agreement on how to divide the continental shelf area between themselves that is without prejudice to the work of the Commission on the Limits of the Continental Shelf.

Southern Area. The Southern Area (Fig. 2) is dominated by the continental Faroe-Rockall Plateau that extends several hundred nautical miles toward the south-west. Three additional states, the United Kingdom, Ireland and Iceland, include the area as part of their outer continental shelf. Geologically and geomorphologically the plateau is characterised by a number of banks and basins where continental crust and older sediments are covered by Palaeogene syn- and post-breakup volcanic strata that are similar to those found on the Faroe Islands. The marginal parts of the plateau are characterised by extensive sediment accumulations, mainly contourites that were deposited by bottom currents along the lower part of the continental slope. The task force is presently preparing the submission documents for the Southern Area and expects to deliver the final documentation to the Ministry of Foreign Affairs by the end of 2010.

\section{Areas of interest - Greenland}

Three areas around Greenland have been defined as areas of interest regarding an extension of the continental shelf beyond 200 NM: an area south of Greenland (including the Eirik Ridge), an area off North-East Greenland near the East Greenland Ridge and an area north of Greenland along the Lomonosov Ridge and in the Amundsen Basin (Figs 3-5). The three areas are briefly described in Marcussen $e t$ al. (2004). As with the Faroe Islands work commercial contractors were used to acquire seismic reflection and bathymetric data. However, because of the sea-ice conditions off NorthEast and North Greenland data from these regions have been acquired in cooperation with Canada and Sweden.

Area south of Greenland. The region south of Greenland (Fig. 3) is characterised by a fairly narrow shelf and by thick sedimentary successions between Greenland and Canada, especially within the extinct spreading zone. The main tasks 


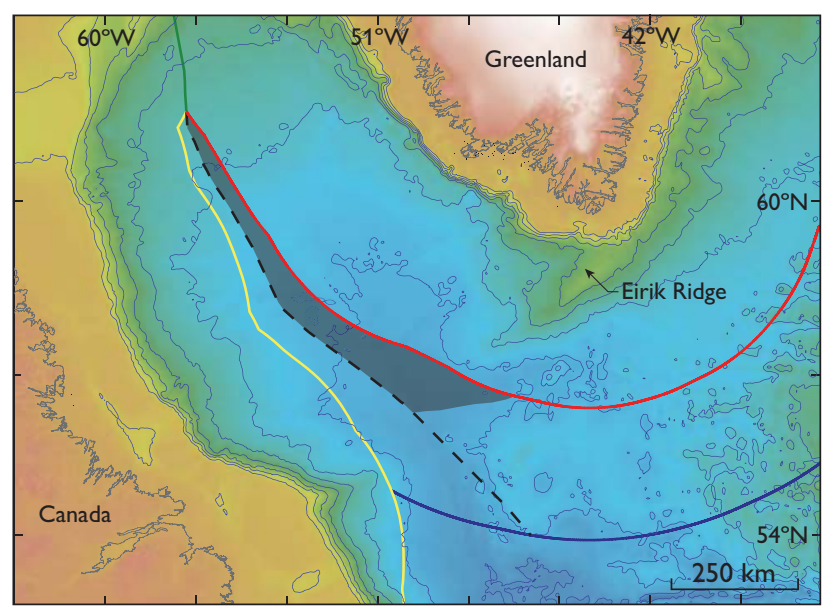

Fig. 3. The potential claim area off southern Greenland (grey tone) has a size of approximately $45000 \mathrm{~km}^{2}$. Green: agreed border within 200 NM. Red: Greenland's EEZ. Yellow: Canada's EEZ. Blue: 350 NM limit. Dashed line: unofficial median line between Greenland and Canada.

in this region are threefold: to map the bathymetry of the continental slope especially along the Eirik Ridge in order to outline the foot of the continental slope, to map the sediment thickness and to investigate the nature of the Eirik Ridge.

Two seismic surveys were carried out in 2003 and 2006 to map the sediment thickness. A total of $c .4000 \mathrm{~km}$ of data were acquired. Other already existing commercial and scientific data supplement these acquired data. In 2008 the bathymetry of the continental slope and parts of Eirik Ridge was mapped by multibeam echo sounding. This data set was supplemented in 2009 with data acquired during a German research cruise (Uenzelmann-Neben 2009). Also in 2009, a joint Canadian-Danish cruise mapped the deeper structure of the Eirik Ridge using refraction seismic profiling (Funck et al. 2009). Data acquisition in the area south of Greenland within the Continental Shelf project is now completed and a task force will prepare the submission documents for this area in 2011.

Area north-east of Greenland. This region (Fig. 4) is characterised by a wide continental shelf. The East Greenland Ridge is assumed to be a natural prolongation of north-eastern Greenland.

In the summer of 2002, GEUS and the University of Bergen carried out a joint seismic refraction and reflection survey of the East Greenland Ridge. Interpretations of the refraction data show that the velocity structure of the East Greenland Ridge is consistent with continental crust (Døssing et al. 2008). During the LOMROG I cruise with the Swedish icebreaker Oden bathymetric mapping of the East Greenland Ridge and the continental slope of the East Greenland shelf

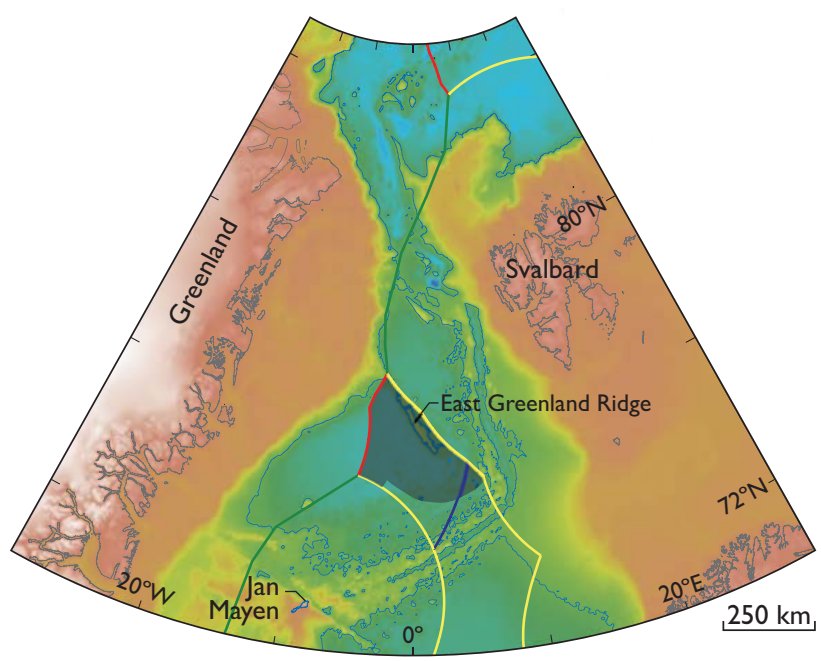

Fig. 4. The potential claim area off North-East Greenland (grey tone) with an approximate size of $63000 \mathrm{~km}^{2}$. Green: agreed boundaries within the 200 NM limit between Greenland-Svalbard and Greenland-Jan Mayen. Red: Greenland's EEZ. Yellow: Norway's EEZ from Svalbard and Jan Mayen. Blue: 350 NM limit.

south-west of the ridge was initiated. The plan is to complete this mapping over the next few years and to supplement it with seismic data and geological sampling.

Area north of Greenland. The Lomonosov Ridge and the Morris Jesup Rise are assumed to be natural prolongations of northern Greenland (Fig. 5). Older seismic data from the Amundsen Basin have shown sediments with sufficient thickness to be used in extending the continental shelf (Weigelt \& Jokat 2001).

Due to the difficult year-round sea-ice conditions in this region and the lack of appropriate Danish logistical possibilities and research platforms, data collection in this area requires cooperation with other countries (MacDougall et al. 2008). Therefore, in 2005 a Memorandum of Understanding was signed with Canada that forms the basis for six major data acquisition programmes mainly in the area north of Greenland.

In the spring of 2006, seismic refraction data were collected from the sea ice during the LORITA expedition (Jackson \& Dahl-Jensen 2007). Field work in the spring of 2009 concentrated on bathymetric and gravimetric data acquisition supplemented by aerogeophysical measurements. In order to acquire seismic data under difficult ice conditions, a seismic reflection acquisition system has been developed in cooperation with the Department of Earth Sciences, Aarhus University, based on experience gained from other surveys in the Arctic by Canadian, German, Norwegian and US institutions. By cooperating with the Swedish Polar Research Secretariat it was possible to use Oden during two cruises (Jakobsson $e t$ 


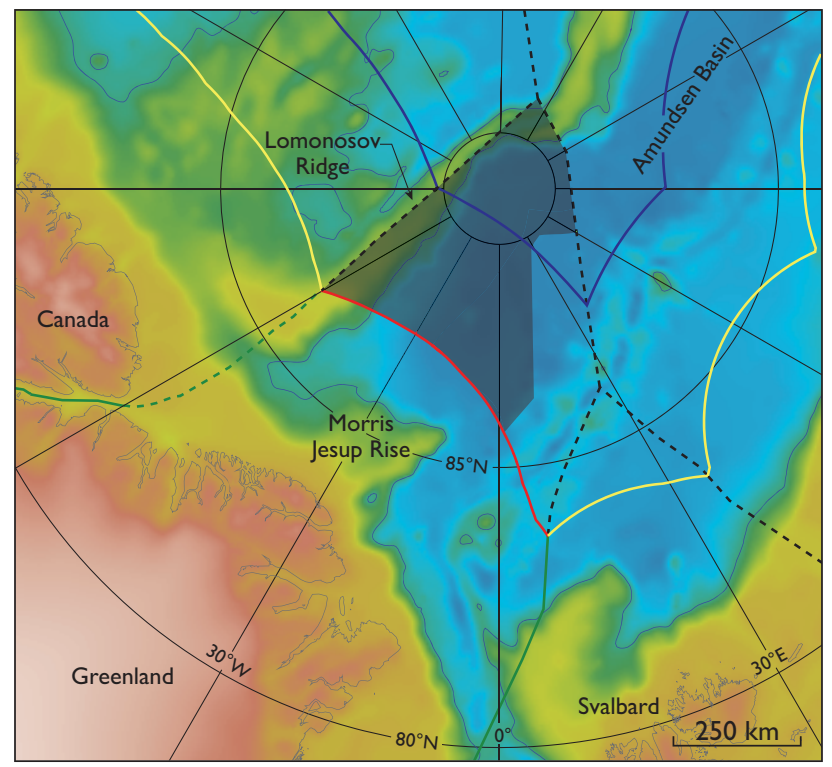

Fig. 5. The potential claim area off North Greenland (grey tone) can have a size up to $150000 \mathrm{~km}^{2}$. Red: Greenland's EEZ. Yellow: Canada's, Norway's and the Russian Federation's EEZ. Blue: the 350 NM limit. Green: the agreed boundaries within 200 NM between Greenland-Svalbard and Greenland-Canada. Stippled green line: Greenland's EEZ north of the agreed boundary with Canada (1973, but within 200 NM). Black stippled lines: unofficial median lines.

al. 2008, Marcussen et al. 2010). Further work is planned for either 2011 or 2012. Since 2007 the Canadian, Russian and Danish continental shelf projects have discussed scientific issues regarding the Lomonosov Ridge on a regular basis.

\section{Conclusions}

Since the start of the project the work has progressed according to plan and submissions for the two Faroese areas will be completed in 2010. Data acquisition is complete for the area south of Greenland. Due to difficult ice conditions, work in the areas north-east and north of Greenland will not be completed until the end of 2014.

Due to the high number of submissions received by the Commission on the Limits of the Continental Shelf, final processing of the two partial submissions for the Faroe Islands may not start until several years after the submissions. The Commission on the Limits of the Continental Shelf could spend 1-2 years considering the documents before reaching a conclusion and submitting a recommendation for the final outer limits of the continental shelf.

\section{References}

Commission on the Limits of the Continental Shelf 1999: Scientific and Technical Guidelines of the Commission, CLCS/11 (http:// www.un.org/Depts/los/clcs_new/commission_documents.htm\# Guidelines).

Døssing, A., Dahl-Jensen, T., Thybo, H., Mjelde, R. \& Nishimura, Y. 2008: East Greenland Ridge in the North Atlantic Ocean: an integrated geophysical study of a continental sliver in a boundary transform fault setting. Journal of Geophysical Research 113, B10107, 33 pp.

Funck, T., Dehler, S.A., Chapman, C.B., Delescluse, M., Iuliucci, J., Iuliucci, R., Judge, W., Meslin, P. \& Ruhnau, M. 2009: Cruise report of the SIGNAL 2009 refraction seismic cruise (Hudson 2009-019). Danmarks og Grønlands Geologiske Undersøgelse Rapport 2009/74, 60 pp., 2 appendices +1 CD.

Jackson, H.R. \& Dahl-Jensen, T. (eds) 2007: Field report for LORITA 2006 - Lomonosov Ridge test of appurtenance. Danmarks og Grønlands Geologiske Undersøgelse Rapport 2007/5, 184 pp.

Jakobsson, M., Marcussen, C. \& LOMROG Scientific Party 2008: Lomonosov Ridge off Greenland 2007 (LOMROG) cruise report, 122 pp. Copenhagen: Geological Survey of Denmark and Greenland.

MacDougall, J.R., Verhoef, J., Sanford, W. \& Marcussen, C. 2008: Challenges of collecting data for Article 76 in ice covered waters of the Arctic. 5th ABLOS Conference Difficulties in Implementing the Provisions of UNCLOS 15-17 October 2008, 21 pp. (http://www.gmat.unsw.edu. au/ablos/ABLOS08Folder/Session4-Paper1-Macdougall.pdf).

Marcussen, C., Christiansen, F.G., Dahl-Jensen, T., Heinesen, M., Lomholt, S., Møller, J.J. \& Sørensen, K. 2004: Exploring for extended continental shelf claims off Greenland and the Faroe Islands - geological perspectives. Geological Survey of Denmark and Greenland Bulletin 4, 61-64.

Marcussen, C. \& LOMROG II Scientific Party 2010: LOMROG II - continued data acquisition in the area north of Greenland. 2009 yearbook of the Swedish Polar Research Secretariat, Stockholm, 43-51. (http:// www.polar.se/organisation/pdf/yearbook2009.pdf).

Memorandum of Understanding between the Earth Sciences Sector of the Department of Natural Resources of Canada and the Geological Survey of Denmark and Greenland of the Ministry of the Environment of Denmark concerning cooperation relating to the delineation of their continental shelves, signed 21 June 2005.

The Government of the Kingdom of Denmark together with the Government of the Faroes 2009: The continental shelf north of the Faroe Islands. Partial submission. Executive Summary, 20 pp. (http://a76.dk/ xpdf/dnk2009executivesummary_s.pdf).

Uenzelmann-Neben, G. (ed.) 2009: The expedition of the research vessel 'Maria S. Merian' to the Labrador Sea in 2009 (MSM 12/2) Reykjavik - Reykjavik 17 June - 13 July 2009. Berichte zur Polar- und Meeresforschung 599, 91 pp. (http://hdl.handle.net/10013/epic.33539).

Weigelt, E. \& Jokat, W. 2001: Peculiarities of roughness and thickness of oceanic crust in the Eurasian Basin, Arctic Ocean. Geophysical Journal International 145, 505-516.

\footnotetext{
Authors' addresses

C.M., Geological Survey of Denmark and Greenland, Øster Voldgade 10, DK-1350 Copenhagen K, Denmark. E-mail: cma@geus.dk M.V.H., Faroese Earth and Energy Directorate (Jarðfeingi), Brekkutún 1, 188 Hoyvik, Faroe Islands.
} 